\title{
Nutritional and Organoleptic Changes of Grass Carp (Ctenopharyngodon idella, Valenciennes, 1844) Meat upon Smoking and Thermal Processing
}

\author{
Vishnu R. Nair ${ }^{*}$, P. Dona ${ }^{2}$, Sajan George ${ }^{3}$ and Lakshmi R.G. Kumar ${ }^{4}$ \\ ${ }^{1}$ QAM Divison, ${ }^{4}$ Biochemistry and Nutrition Division, ICAR-Central Institute of Fisheries \\ Technology, Cochin, India \\ ${ }^{2}$ ICAR-Central Institute of Fisheries Education, Mumbai, India \\ ${ }^{3}$ School of Aquatic Food Products and Technology, Kerala University of Fisheries and Ocean \\ Studies, Cochin, India \\ *Corresponding author
}

\section{A B S T R A C T}

\begin{tabular}{|c|}
\hline Keywords \\
\hline $\begin{array}{l}\text { Carp, Nutritional } \\
\text { quality, Sensory } \\
\text { quality, Thermal } \\
\text { processing }\end{array}$ \\
\hline Article Info \\
\hline $\begin{array}{l}\text { Accepted: } \\
22 \text { July } 2018 \\
\text { Available Online: } \\
10 \text { August } 2018\end{array}$ \\
\hline
\end{tabular}

Presence of intramuscular bones, muddy flavour and soft texture of meat are the major constraints which reduces consumer acceptability of carps. A study was under taken in order to find out the effects of smoking and thermal processing on nutritional and organoleptic quality of grass carp meat. Mildly smoked $(2.5 \mathrm{~h})$ at $700 \mathrm{C}$ grass carp packed in retort pouches and cans was processed to various $\mathrm{F}_{0}$ values $(2,4,6,8$ and $10 \mathrm{~min})$ at a temperature of $121.1^{\circ} \mathrm{C}$. Nutritional quality parameters, thiamine content and pepsin digestibility has decreased with the increase in extent of thermal processing. Influence of type of container (cans and retortable pouches) on nutritional quality were also compared and found that retort pouch processed product as superior. Muddy flavour was not perceived in any of the products and texture of meat found improving with extent of thermal process. The products processed at $121.1^{\circ} \mathrm{C}$ for $\mathrm{F}_{0}$ value of 6 and 8 min were found commercially sterile. Therefore, considering nutritional quality, sensory quality and extent of sterilization, thermal process for an $\mathrm{F}_{0}$ value of 6 min could be recommended.

\section{Highlights}

Smoking of fillets before thermal processing was found advantageous for reducing muddy flavour and improving the sensory quality of retort pouch processed product.

The products processed at $121.1^{\circ} \mathrm{C}$ for $\mathrm{F}_{0}$ value of 6 were found to be better in terms of nutritional, textural and organoleptic quality. Retort pouch processed products are superior in nutritional quality as compared to canned product.

\section{Introduction}

Aquaculture is one of the fastest growing industries in India. According to the latest available statistics by FAO, India stands second in aquaculture production. The bony fishes including Indian major carps, viz., catla, rohu and mrigal, together with the three 
exotic carps, viz., silver carp, grass carp and common carp, form a major component of Indian aquaculture due to their low cost of production and good marketing potential. Even though there is great potential for processing of carps for internal market as well as for export, the growth of the industry is not very appreciable. According to Gopal et al., (2012) the presence of inter muscular bones and consumer perception of muddy flavour are the major reasons for the lower acceptability of the fish. Muddy flavour in freshwater fishes is mainly due to the presence of geosmin compound synthesised by blue green algae and actinomycetes. Fish absorbs it from water through gills, and after passing digestive tract, it is finally deposited in fat tissues. This consequently affects the flavour of fish flesh (Lovell, 1979). Studies have shown that combination of smoking and thermal processing can be advantageous; smoking masks muddy flavour and thermal processing considerably softens the bones (Vijayan et al., 1998). One of the most common methods for processing freshwater fishes to a marketable end product is smoking. Smoke curing is a traditional fish preservation method of considerable economic importance worldwide. Nearly $2 \%$ of world's fish catch is used for preparing smoked products. Nowadays smoking process is mainly used in food processing sector with an intension of imparting typical flavour and other desirable organoleptic qualities to the smoked foods. However, till now little attention has been given in India to develop smoke curing of fish.

Thermal processing technique emphasizes the achievement of commercial sterility while minimising the changes in nutritional value and eating quality (Holdsworth and Simpson, 2007). Conventional canning operations have the tendency to induce adverse changes to the nutritional and sensory attributes of foods. It has been established that for the same extent of microbial sterilization given, heating for a longer period at a lower temperature is more detrimental to the sensory and nutritional qualities of food than heating at a higher temperature but for a shorter period.

Various processing steps can have negative impact on the nutritional quality of the proteins. One means of assessing it is by determining the protein digestibility (Hryniewiecki, 2000). During smoking and thermal processing breakage of secondary, tertiary and quaternary structures occurs which unfolds the proteins and improves their bioavailability since peptide bonds become readily accessible to digestive enzymes. Modifications of primary protein structures on the other hand may lower digestibility and produce proteins that are not biologically available.

According to Awuah et al., (2007), vitamins are one among the most sensitive food components to be affected by heating. Heat labile vitamins like thiamine, ascorbic acid, riboflavin, niacin, pyridoxine and panthothenic acid, are the vitamins most damaged by thermal processing. The rate of destruction of thiamine has been found to increase more or less steadily with increase in temperature or time. Thus thiamine content is commonly used as an index of nutritional quality of thermal processed low acid foods. Even though novel heating alternatives could replace conventional thermal processing methods, their adoption would require prior justification in terms of significant quality improvements and economic viability to the food processor.

Smoked fish curry is a ready-to-eat convenience form of product which can have great scope in internal as well as export markets. Grass carp (Ctenopharyngodon idella) was used for the study as a representative of carps. The local fish farmers 
reported that the meat of grass carp is inferior to other cultured fishes and so, the market demand is less and is even lower as compared to other carps. There is a great potential for the processing of freshwater fishes including carps, but the Indian fish processing industry is presently concentrating on marine fishes. The study involved packing smoked fish fillets in retort pouches as well as cans with curry as the packing medium followed by thermal processing. The consumer acceptability and quality of the products were assessed by conducting various tests. The outcome of the study is expected to make retort pouch processed smoked grass carp curry that can achieve greater market demand. In practice improvements have to be done in thermal processing in order to minimise overcooking of the product during sterilization. The studies regarding the nutritional quality are expected to give suggestions to the processor for producing products with minimum nutritional loss.

\section{Materials and Methods}

\section{Materials}

Live grass carp (Ctenopharygodon idella) weighing average of $350 \mathrm{~g}$ was purchased from a fish farm that was then iced and transported in an insulated box to the laboratory within four hours.

\section{Smoking}

The raw material was thoroughly washed with potable water until the surface become clean and totally free of slime. Scales and viscera were removed, washed thoroughly and filleted to pieces of approximately $17.5 \times 7 \times$ $1.1 \mathrm{~cm}$. The skinned fillets were immersed in brine of concentration 5\% for a period of 15 min followed by draining for a period of 30 min under refrigerated condition. Smoking was carried out in a mechanical smoke kiln
(Kerres make, Germany) at a temperature of 700C for $2.5 \mathrm{~h}$ using beech wood chips (3-5 $\mathrm{mm}$ size) as fuel.

\section{Preparation of curry}

Ingredients, as given in Table 1, were weighed out. Malabar tamarind was soaked in warm water for $10 \mathrm{~min}$ and the pulp was squeezed out. Refined oil was heated to frying temperature of $1800 \mathrm{C}$ in a frying pan, to which fenugreek seed and ground onion were added and fried until the onion attained a light brown colour. To this, ground green chilli, ginger, and garlic were added and frying continued for 2-3 min. Turmeric powder, chilli powder and coriander powder were added and frying continued for another few minutes and then removed from flame. Tamarind juice and salt were added to the mixture and boiled for a period of $5 \mathrm{~min}$. The $\mathrm{pH}$ of the curry was then adjusted to 3.5 by addition of tamarind juice.

\section{Thermal process studies}

Retort pouches made of polystyrenealuminium foil-polypropylene laminate of size $15.5 \times 17 \mathrm{~cm}$ and cans made of tin free steel (TFS) of 307 X 109 size were used for packing the products. Smoked grass carp pieces of size of about $3 \times 2.5 \times 0.9 \mathrm{~cm}$, were packed in the pouches and cans. A thermocouple probe inserted into a fish piece in each pack with its tip reaching its centre and was placed in such a manner that the tip of the probe lied at the pre-determined cold spot. To this hot curry was added in the proportion, fish: curry $=50: 50$ (weight by weight). Immediately upon adding hot curry the pouches were sealed using a pneumatic sealer and cans by a double seamer. The packs were loaded into a still overhead pressure retort operated using steam and compressed air. The thermocouple lead wires were taken out of the retort through a gland 
and were connected to thermocouple data recorder (Ellab make, Denmark). The process temperature adopted was $121.1^{\circ} \mathrm{C}$. The extent of sterilization achieved in the product by thermal processing was calculated as $\mathrm{F}_{0}$ value. The reference organism assumed was Clostridium botulinum (type A) spores. Its $\mathrm{Z}$ value of $10^{\circ} \mathrm{C}$ and reference temperature of $121.1^{\circ} \mathrm{C}$ were adopted for calculation. These were programmed in the F-value computer for the various trials. Each lot was processed for the required period in order to obtain $F_{0}$ values of $2,4,6,8$ and $10 \mathrm{~min}$.

\section{Chemical analysis}

The moisture content was determined by the oven drying method of AOAC (1975). The method of AOAC (1984) was followed for ash content estimation. Total nitrogen and crude protein contents were estimated by the micro kjeldahl method of AOAC (1984). The method of AOAC (2000) was followed for determining crude fat content. A sample of 5 $\mathrm{g}$ meat was homogenised with $10 \mathrm{ml}$ of distilled water and $\mathrm{pH}$ was measured using digital $\mathrm{pH}$ meter (Metler Toledo) as per the method of IS: 2168-1971. Pepsin digestibility was determined according to the method of Miller et al., (2000). The colorimetric procedure of Hochberg et al., (1944) was followed for determining thiamine content in the samples.

\section{Commercial sterility}

Commercial sterility of thermal processed samples in retort pouches and cans were estimated according to IS: 2168-1971. The samples were incubated, one lot at $370 \mathrm{C}$ for 15 days and another lot at $55^{\circ} \mathrm{C}$ for 5 days and were observed for any bulging during the incubation period. The incubated samples were aseptically opened; one gram of the contents was aseptically weighed out and inoculated into sterilized thioglycollate broth in test tubes. Liquid paraffin was pipetted out into the tube to form a layer on top of the broth in the test tube. The contents of the pouch were examined for any spoilage. Two tubes each from aerobic and anaerobic conditions, along with blanks were incubated at $37^{\circ} \mathrm{C}$ and $55^{\circ} \mathrm{C}$ for $48 \mathrm{~h}$. The tubes were examined for development of any turbidity in the media.

\section{Sensory analysis}

The sensory quality of the processed samples was presented to a panel of judges in a coded form. They were assigned to evaluate the appearance and colour, texture, taste, overall acceptability, smoke flavour and muddy flavour of each sample and record their judgements in the score sheets provided. They were also assigned to check the texture of fish bones. Sensory scores are calculated according to Meilgaard et al., (2006).

\section{Statistical analysis}

The experiments were carried out using Completely Randomized Design (CRD). Data obtained were analysed using Analysis of Variance (ANOVA) technique (Snedecor and Cochran, 1968). Pair wise comparison of treatment means was done wherever necessary using least significance $(\mathrm{p} \leq 0.05)$. Organoleptic scores were compared using Kruskal-Wallis and related tests (Sprent, 1989).

\section{Results and Discussion}

\section{Effect of smoking on nutritional characteristics of grass carp}

The proximate composition of raw grass carp meat was found to be $78.1 \pm 0.85 \%$ moisture, $18.4 \pm 0.25 \%$ protein, $2.3 \pm 0.05 \%$ fat and $0.9 \pm 0.01 \%$ ash which reveals there are no remarkable variations as compared to 
proximate composition of meats of other carps. Gopal et al., (2012) reported that on an average meat of Indian major carps contains $70-80 \%$ moisture, $15-19 \%$ protein, $3-9 \%$ fat and $1-1.4 \%$ ash.

The changes occurred in chemical parameters of raw grass carp meat upon smoking are shown in Table 2. Smoking for a period of 2.5 $h$ at $70^{\circ} \mathrm{C}$ resulted in reduction of moisture content from $78 \%$ to $51.2 \%$ on account of evaporation of water. Significant differences ( $p \leq 0.05$ ) were observed between smoking periods for both $\mathrm{pH}$ and moisture content. The drop in $\mathrm{pH}$ is probably due to the deposition of carbonyl compounds from wood smoke in meat and compounds aroused from lipid oxidation. Thiamine content of raw grass carp meat was about $86.32 \mu \mathrm{g} / 100 \mathrm{~g}$. Variations are possible because thiamine is not synthesised in fishes and they attain it through the food chain. A decrease in thiamine content was observed upon smoking. Temperature of smoke could be responsible for the thiamine destruction during smoking. Lamden (1972) has also reported that thiamine loss increases with increase in temperature and time.

The nutritive qualities of any food protein are determined by the content of essential amino acids and protein digestibility (Hryniewiecki, 2000). In the present study, pepsin digestibility was used in order to determine the extent of protein digestibility of the product. Pepsin digestibility was found to decrease slightly with smoking (Table 2). Similar observations were reported by Lilabati et al., (1993) during the traditional smoking of silurid fishes. The decrease in protein digestibility is mainly attributed to protein denaturation as result of heat induced rupture of secondary and higher structures of protein (Ledward, 1979 and Unlusayin et al., 2001). The decrease in pepsin digestibility can also be due to the interactions of proteins with the smoke constituents (Lokesh et al., 1989).

\section{Effect of thermal processing on physico- chemical properties of smoked fish}

In the present study fish pieces smoked for a period of $2.5 \mathrm{~h}$ were packed in retort pouches as well as cans and processed to various $F_{0}$ values. The come up time required for the retort to attain a temperature of $121.1^{\circ} \mathrm{C}$ was 8 min. According to Anon, (1968) the come up time should be kept as short as possible in order to achieve faster heat penetration rate. The minimal process lethality $\left(\mathrm{F}_{0}\right)$ required for reducing population of $C$. botulinum through 12 decimal reductions is $2.52 \mathrm{~min}$ (Stumbo, 1973). Even though a minimum $\mathrm{F}_{0}$ value of $3 \mathrm{~min}$ can render the product commercially sterile, a much higher $\mathrm{F}_{0}$ value is often adopted in order to guarantee a microbiologically safe product. The $\mathrm{F}_{0}$ value recommended by Frott and Lewis (1994) for fish and fish products ranges from 5 to 20 min. Operator's process time required for retort pouch packed products processed at $121.1^{\circ} \mathrm{C}$ to achieve $\mathrm{F}_{0}$ value of $2 \mathrm{~min}$ was 7 min whereas it increased to $8 \mathrm{~min}, 9 \mathrm{~min}, 11$ min and 13 min for achieving $F_{0}$ values of 4 , 6,8 and 10 respectively. Whereas in case of cans it took 13, 15, 17, 19, and $21 \mathrm{~min}$ for achieving $F_{0}$ values of 2, 4, 6, 8 and $10 \mathrm{~min}$ respectively. The shorter process time required for the pouch could be attributed to (i) lower thickness of product and hence, cold spot lying closer to surface and (ii) higher surface area to volume ratio for pouch aiding heat penetration (Mohan et al., 2008).

The solid: liquid proportion of fish curry was 50:50 by weight at the time of packing. This was changed to $60: 40$ upon processing in pouch. The lower moisture content of smoked fish pieces may have a tendency to absorb water from the curry which could be the reason for the weight gain. Therefore, a 
separate precooking step could be avoided if smoked fish of sufficiently lower moisture content is used for packing. However, the extent of smoking should be optimised in order to obtain a stable solid weight without affecting the product flavour.

Curry with a $\mathrm{pH}$ of 3.5 was used as the packing medium for all the trials. $\mathrm{pH}$ of the unprocessed product was 5.13 and increased to 5.75 when processed for an $\mathrm{F}_{0}$ of $2 \mathrm{~min}$; thereafter a decreasing trend was observed with increase in $\mathrm{F}_{0}$ value (Fig. 1). According to Hamm (1966) increase in $\mathrm{pH}$ during heating could be attributed to charge changes, hydrogen bonding or a combination of both which take place within myofibrillar proteins. Similarly, with the increase in heating, the splitting of hydrogen bonds and release of $\mathrm{H}+$ into the product might have occurred and that could be the reason for drop in $\mathrm{pH}$ (Correia and Mittal, 1991). They also proposed that the loss of basic amino groups due to maillard reaction will also cause drop in $\mathrm{pH}$. Bindu (2009) also observed a decrease in $\mathrm{pH}$ value by 0.02 unit during the processing of smoked tuna pieces packed in retort pouches for an $\mathrm{F}_{0}$ value of $10 \mathrm{~min}$.

Thiamine destruction can be used as an indicator of nutritional loss in thermal processed food. In the case of products packed in retort pouches and processed at a temperature of $121.1^{\circ} \mathrm{C}$, thiamine content showed a decreasing trend with increase in the extent of sterilization (Fig. 2). Products that were not thermal processed contained $63.26 \mu \mathrm{g} / 100 \mathrm{~g}$ thiamine, whereas the content dropped to $44.94 \mu \mathrm{g} / 100 \mathrm{~g}$ in retortable pouches and $38.91 \mu \mathrm{g} / 100 \mathrm{~g}$ in cans when processed to an $\mathrm{F}_{0}$ value of $10 \mathrm{~min}$. According to Tannenbaum (1976) thiamine destruction rate is a function of temperature, time of heating and the $\mathrm{pH}$ of the packing medium. Kong et al., (2007) have reported considerable variations in thiamine content during the thermal processing of salmon meat. They observed that thiamine content was $2.03 \mu \mathrm{g} / \mathrm{g}$ in raw salmon meat and was reduced to $0.4 \mu \mathrm{g} / \mathrm{g}$ when subjected to a thermal process of $30 \mathrm{~min}$ at a temperature $121.1^{\circ} \mathrm{C}$. Stability of thiamine can also decrease with increase in $\mathrm{pH}$ (Lamden, 1972). Briozzo et al., (1987) found that with reduction in $\mathrm{pH}$ from 6.9 to 5.0 the thiamine loss of canned pea, corn, and beef liver purees has dramatically decreased. They recommended that a mild reduction in $\mathrm{pH}$ of food could minimise thiamine loss in canned low acid food.

Heat denaturation of proteins does not necessarily cause nutritional loss (Aubourg, 2001) but may reduce digestibility of protein (Opstvedt et al., 1984). Modifications of primary protein structures due to heat denaturation may lower digestibility and produce proteins that are not biologically available (Swaisgood, 1985). In the present study, protein quality of thermal processed smoked grass carp meat was evaluated by estimating pepsin digestibility. Pepsin digestibility of retort pouched grass carp was found decreasing significantly with increase in the $\mathrm{F}_{0}$ value $(\mathrm{p} \leq 0.05)$ (Fig. 3). Unprocessed products were observed to have $93.78 \%$ pepsin digestibility and was found to decrease with increase in the extent of sterilization given. Canning reduced pepsin digestibility from $93.78 \%$ in unprocessed fish pieces to $83.50 \%$ whereas by retort pouch processing it was reduced only to $87.15 \%$. This is probably due to the greater period of heating required for canned product $(21 \mathrm{~min})$ compared to that for retort pouch processed product (13 min). A similar observation was made by Tanaka and Kimura (1988) who reported a reduction in pepsin digestibility by $6 \%$ when big eye tuna packed in flexible containers was processed at temperature of $1150 \mathrm{C}$ and $1240 \mathrm{C}$ to different $\mathrm{F}_{0}$ values. 
Table.1 Ingredients of fish curry

\begin{tabular}{|c|c|}
\hline Ingredient & Weight $(\mathbf{g})$ \\
\hline Smoked fish & 1000 \\
\hline Onion & 60 \\
\hline Ginger & 13 \\
\hline Green chillies & 25 \\
\hline Fenugreek & 0.8 \\
\hline Turmeric powder & 2.5 \\
\hline Chilli powder & 60 \\
\hline Coriander powder & 20 \\
\hline Oil & 50 \\
\hline Salt & 16 \\
\hline Water & 500 \\
\hline Malabar tamarind & 50 \\
\hline
\end{tabular}

Table.2 Variations in chemical parameters in raw grass carp meat on smoking for $2 \mathrm{~h}$ at $70^{\circ} \mathrm{C}$

\begin{tabular}{|c|c|c|}
\hline Parameter & Raw & Smoked (2h) \\
\hline Moisture $(\boldsymbol{\%})$ & $78.1 \pm 0.85$ & $51.2 \pm 0.71$ \\
\hline $\mathbf{p H}$ & $6.6 \pm 0.02$ & $6.36 \pm 0.05$ \\
\hline $\begin{array}{c}\text { Thiamine content }(\boldsymbol{\mu g} / \mathbf{1 0 0} \\
\text { g) }\end{array}$ & $86.32 \pm 1.02$ & $63.89 \pm 0.68$ \\
\hline Pepsin digestibility $(\boldsymbol{\%})$ & $96.11 \pm 1.15$ & $93.38 \pm 0.92$ \\
\hline
\end{tabular}

All the means are significantly different.

Table.3 Survival of microorganisms in retort pouch packed grass carp curry subjected to various extents of thermal processing

\begin{tabular}{|c|c|c|c|c|}
\hline \multirow{2}{*}{$\mathrm{F}_{\mathrm{o}}$ value } & \multicolumn{2}{|c|}{ Aerobic } & \multicolumn{2}{c|}{ Anaerobic } \\
\cline { 2 - 5 } & $37^{0} \mathrm{C}$ & $55^{\circ} \mathrm{C}$ & $37^{\circ} \mathrm{C}$ & $55^{\circ} \mathrm{C}$ \\
\hline 2 & - & - & + & + \\
\hline 4 & - & - & - & + \\
\hline 6 & - & - & - & - \\
\hline 8 & - & - & - & - \\
\hline 10 & - & - & - & - \\
\hline
\end{tabular}




$$
\begin{array}{r}
6 \\
5 \\
4 \\
3 \\
3 \\
2 \\
1 \\
0
\end{array}
$$

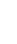

$\begin{array}{lllrrr}0 & 2 & 4 & 6 & 8 & 10 \\ & & \mathrm{~F}_{0} \text { Value }(\min ) & & \end{array}$

Retortable poches Cans

Fig.1 Variations in $\mathrm{pH}$ of grass carp curry packed in retort pouch and cans subjected to various extents of thermal processing at $121.1^{\circ} \mathrm{C}$

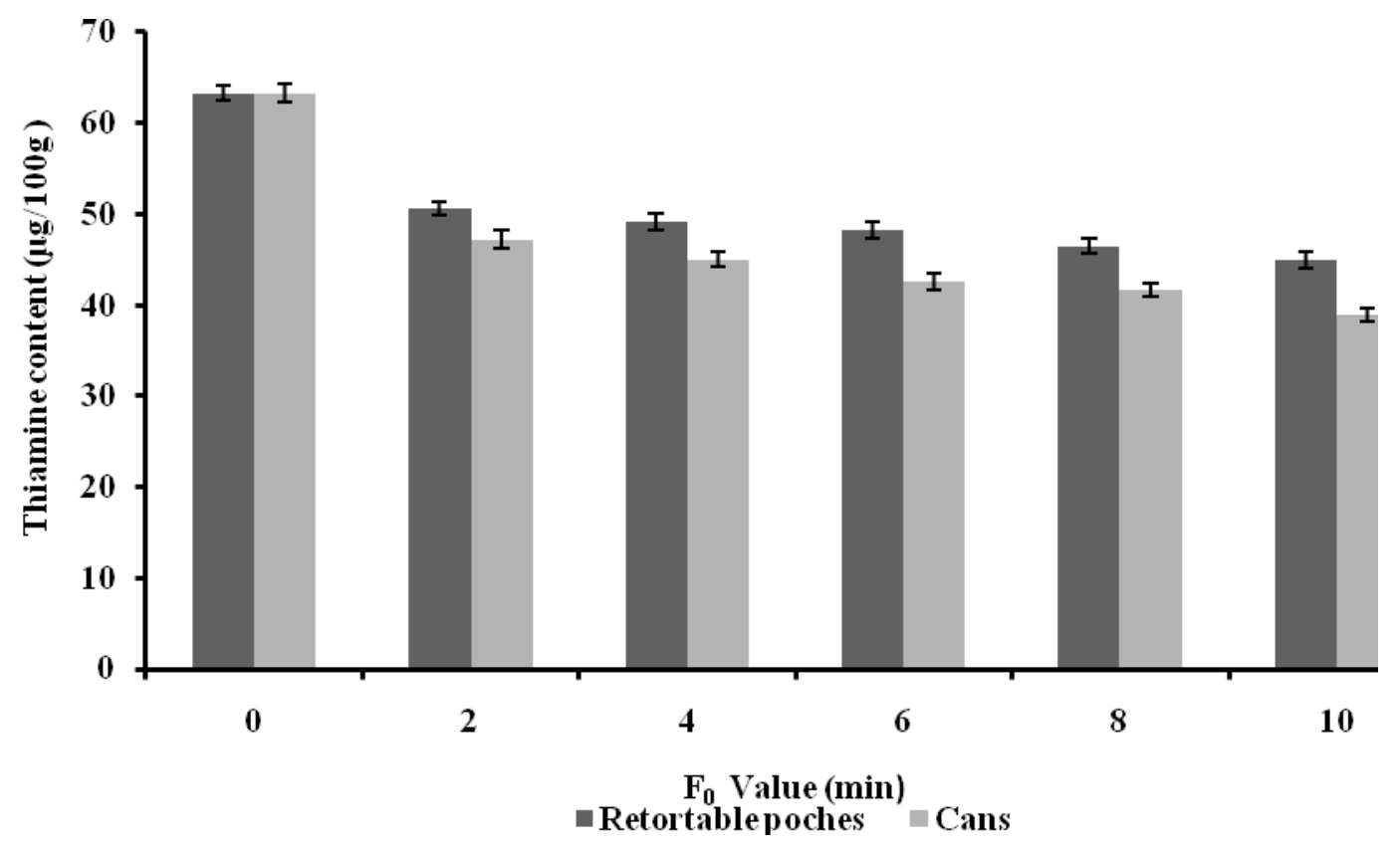

Fig.2 Variations in thiamine content of grass carp curry packed in retort pouch and cans subjected to various extents of thermal processing at $121.1^{\circ} \mathrm{C}$ 


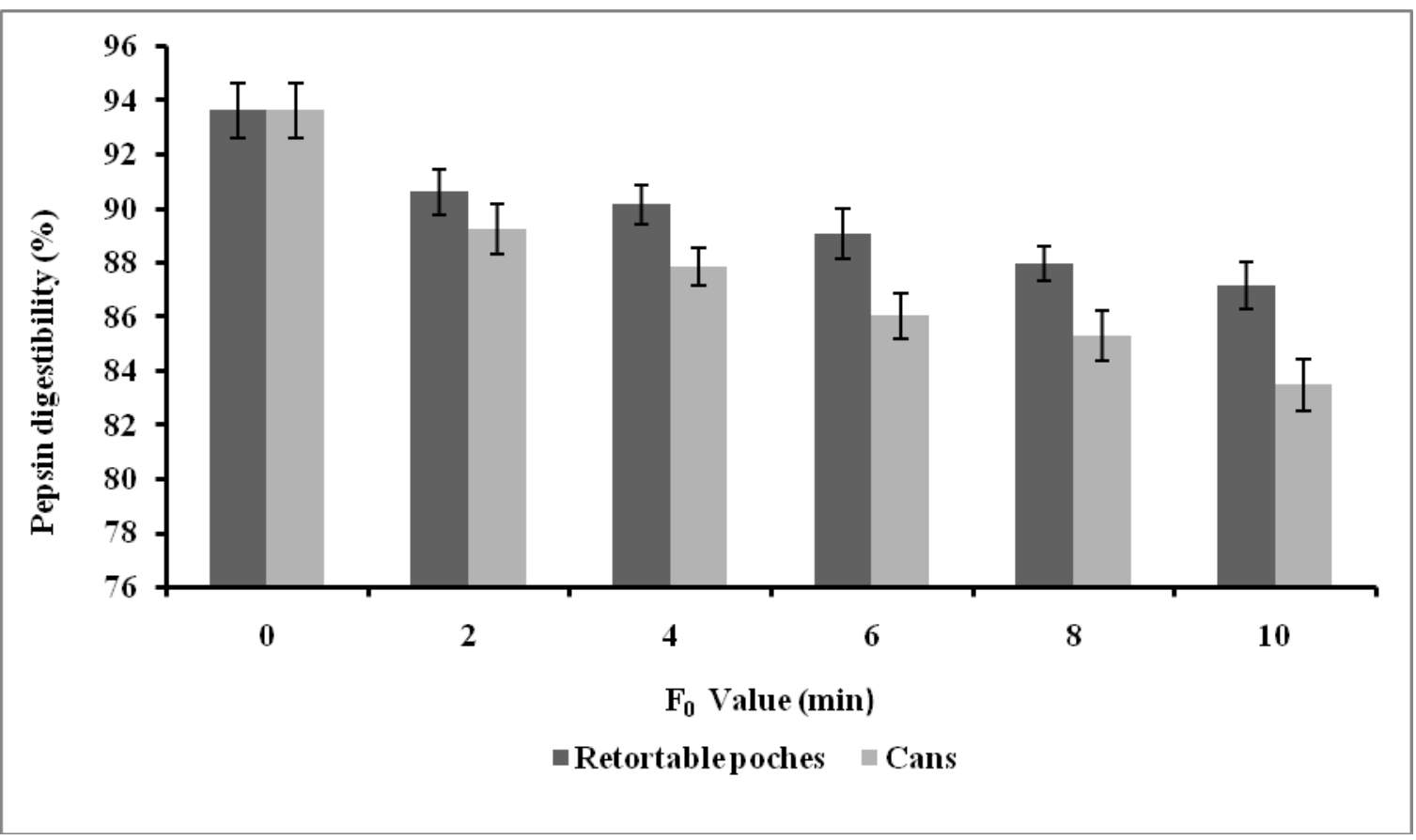

Fig.3 Variations in pepsin digestibility of grass carp curry packed in retort pouch and cans subjected to various extents of thermal processing at $121.1^{\circ} \mathrm{C}$

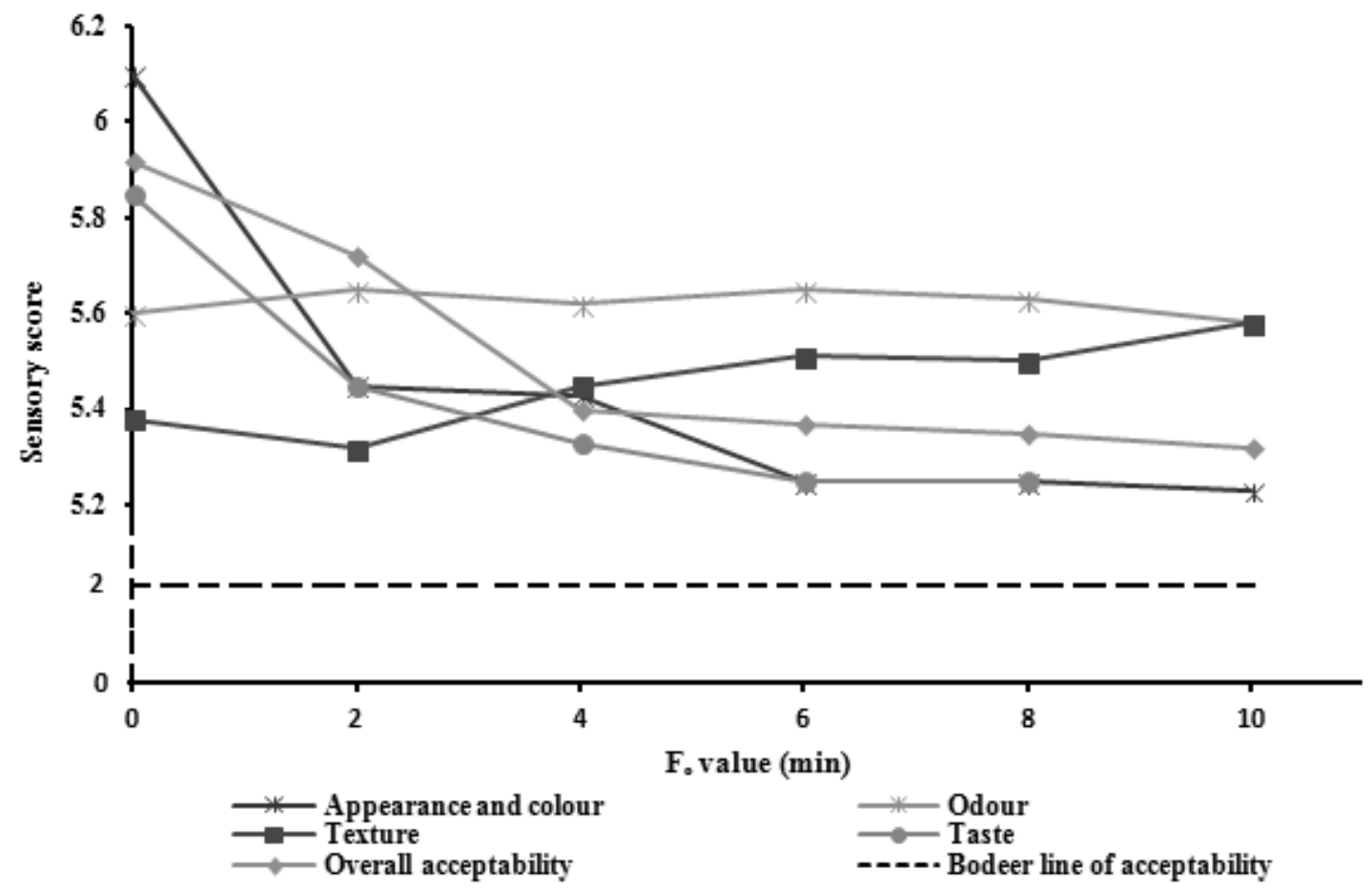

Fig.4 Sensory evaluation scores of retort pouch processed grass carp curry subjected to various extents of thermal processing 


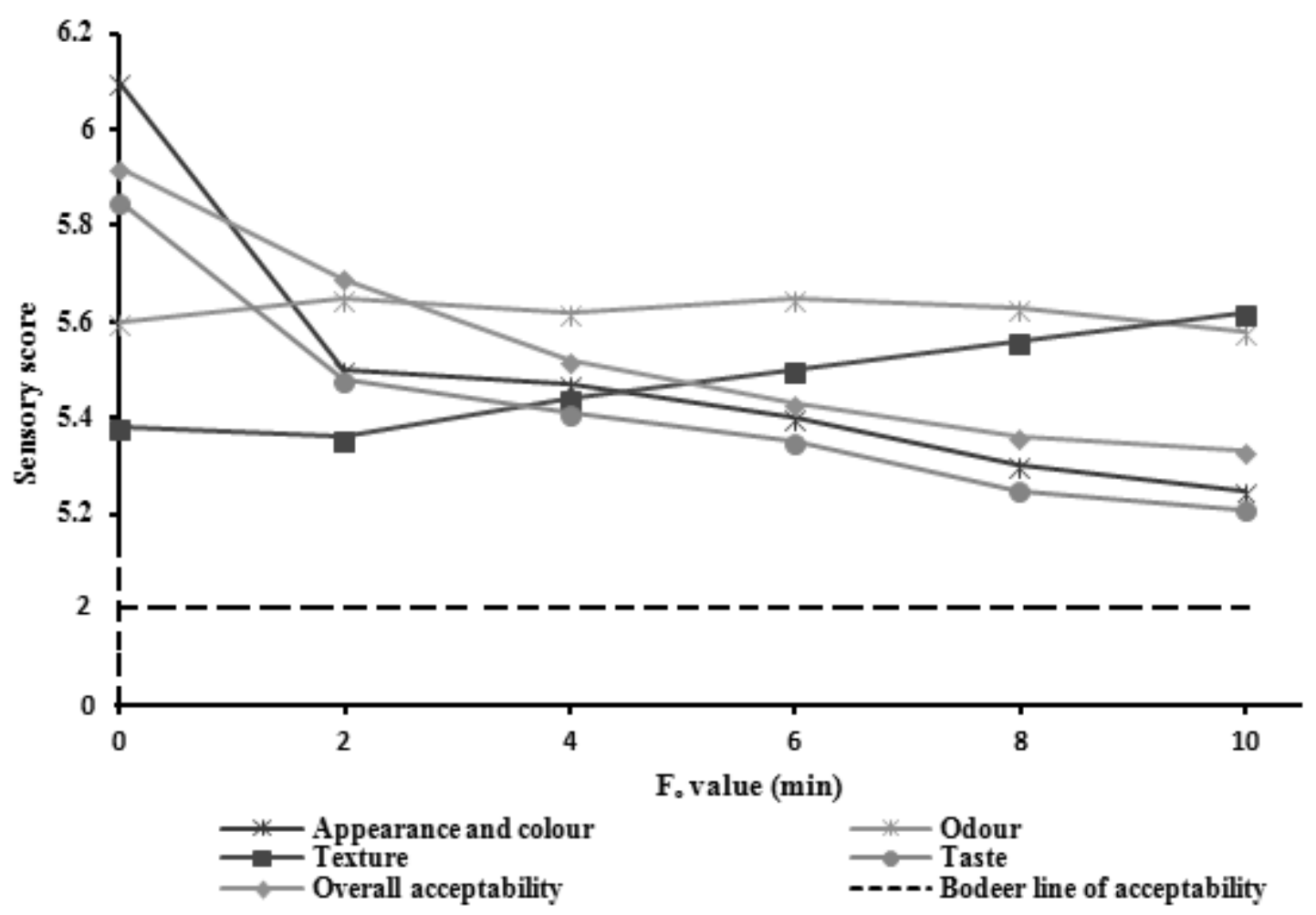

Fig.5 Sensory evaluation scores of canned grass carp curry subjected to various extents of thermal processing

Denaturation of proteins that occurred during heating may be the reason for reduction in pepsin digestibility (Unusyayin et al., 2001). However, Baga et al., (1992) found that canning of tuna at a temperature of $1250 \mathrm{C}$ and $\mathrm{F}_{0}$ values less than $12 \mathrm{~min}$ had only slight effect on protein digestibility. Zygmunt et al., (2009) observed that canned fish were characterized by lower protein digestibility (between $90.6 \%$ and 95.4\%) than smoked, marinated or salted products and they inferred that it could be of drastic thermal process given during canning.

Sensory scores obtained for all the products (Cans and Retortable pouches) for each parameter were well above the borderline of acceptability score of 2 (Fig. 4 and 5) indicating that the products were of high sensory quality. Significant variations were not observed in the sensory quality between canned and retort pouch processed product. The unprocessed products obtained highest sensory scores for all the parameters except for texture and odour. The sensory properties such as flavour, colour, and texture are very heat sensitive and therefore a reduction in the score for these parameters may have occurred in all the thermal processed products. However, significant differences were not observed between the extents of thermal process for any of the sensory evaluation parameters as per the statistical analysis $(\mathrm{p} \leq$ 0.05 ). This means that even in a well sterilized product ( $F_{0}$ of $\left.10 \mathrm{~min}\right)$, the sensory quality loss is minimal.

Some of the major constraints regarding thermal processing of carp meat are the soft texture of meat and excess precipitation of proteins which make the product unattractive (Vijayan et al., 1998). In the present study protein precipitation was not observed in any of the products. The texture of the meat was firm in all cases which could be due to the effect of smoking. Textural quality was found 
to increase with the extent of sterilization in both cans and retortable pouches. It could be an indication that hardened texture of meat after smoking may considerably get softened with an increase in thermal process. Ali et al., (2005) observed a softening of retort pouch processed sardine meat upon thermal processing to higher $\mathrm{F}_{0}$ values.

Smoked fish pieces which were not thermal processed were rated superior in taste. This may be because of mild cooking of meat imparted by smoking and the fresh flavour of spices in the curry medium. The taste scores were found decreasing slightly with an increase in $\mathrm{F}_{0}$ value which could be due to the loss of heat labile taste components as a result thermal processing. Although slight changes in the sensory scores were seen in the scoring of the parameters, the overall acceptability scores were not affected by the extent of process given. Thus it may be concluded that the sensory quality of the product is stable over a wide range of thermal process conditions.

Persistence of smoke flavour was observed in all the products processed in cans and retotable pouches. Marked variations were not found between sensory score obtained for the products processed from $\mathrm{F}_{0}$ value 2 to $10 \mathrm{~min}$. However, none of the sensory panelists have perceived muddy flavour in any of the products. Vijayan et al., (1998) reported that partial drying for a period of $2 \mathrm{~h}$ followed by smoking had masked the muddy flavour and improved the texture of meat in canned catla. Mild processing and curry ingredients could effectively mask or destroy the muddy flavour. One of the characteristics of well processed canned fish is that the small bones become easily crushable and chewable upon thermal processing. However, in the retort pouch processed products bones were not chewable even in well sterilized product $\left(\mathrm{F}_{0}\right.$ of $10 \mathrm{~min}$ ). Slight softening of bones was observed in canned product processed to an $\mathrm{F}_{0}$ value of $10 \mathrm{~min}$. This could be due to significantly shorter process time required to achieve the required $F_{0}$ value compared to canned products.

Technological improvements have to be done in thermal processing in order to minimise overcooking of the product during sterilization. Considering nutritional quality it is desirable to minimize the thermal process sufficient enough to achieve commercial sterility without sacrificing sensory attributes. The results of microbiological tests are given in the Table 3. During the incubation period at a temperature of $37^{\circ} \mathrm{C}$ and $55^{\circ} \mathrm{C}$, all pouches appeared normal without any bulging. Presence of both mesophilic and thermophilic organisms was observed in products processed to an $F_{0}$ value of 2 min whereas products processed to an $\mathrm{F}_{0}$ value of $4 \mathrm{~min}$ showed presence of only thermophilic organisms. Products processed at $121.1^{\circ} \mathrm{C}$ for $F_{0}$ values of 6,8 and $10 \mathrm{~min}$ were found commercially sterile.

Considering the products achieved commercial sterility, the sensory scores were well above the borderline of acceptability. Smoking the fillets before thermal processing was found advantageous for reducing muddy flavour and improving the sensory quality of retort pouch processed product. The extent of loss of nutritional indicators, viz., thiamine content and pepsin digestibility were also not high and well within the acceptable limits. Therefore considering nutritional quality, sensory quality and extent of sterilization, thermal process for an $\mathrm{F}_{0}$ value of 6 min could be recommended for retort pouch processed smoked grass carp curry. Application of higher temperature (generally not beyond $121.1^{\circ} \mathrm{C}$ ) and use of retort pouches instead of cans are also suggested for better nutrient retention in thermal processed products. However, product development and 
standardization of thermal process should be in such a way as to achieve commercial sterility and provide maximum retention of quality parameters.

\section{References}

Ali, A., Sudhir, B. and Gopal, T.K.S. 2005. Effect of Heat Processing on the Texture Profile of Canned and Retort Pouch Packed Oil Sardine (Sardinella longiceps) in Oil Medium. J. Fd. Sci. 70(5): 350-354

AOAC. 1975. Official Methods of Analysis. Association of Official Analytical Chemists, Washington, 12th Edn., p. 1094.

AOAC. 1984. Official Methods of Analysis. Association of Official Analytical Chemists, Washington, 14th dn., p. 1141.

AOAC. 2000. Official Methods of Analysis. Association of Official Analytical Chemists, Washington, 17th Edn., p. 1218.

Aubourg, S.P. 2001. Loss of quality during the manufacture of canned fish products. Fd. Sci. Technol. Int. 7 (3): 199-215

Awuah, G., Ramaswamy, H. and Economides, A. 2007. Thermal processing and quality: Principles and overview. Chem. Engng and Processing. 46(6): 584-602.

Baga, J.R., Alonso, A.A., Gallardo, J.M. and Perezmartin, R.I. 1992. Degradation kinetics of protein digestibility and available lysine during thermal processing of Tuna. J. Fd. Sci. 57 (4): 913-915.

Bindu. J. 2009. Thermal processing of smoked yellow fin tuna (Thunnus albacares) in flexible pouches. Ph.D thesis, Cochin University of Science and Technology, Cochin, pp 141-142.
Briozzo, J., Basualdo, R.N., Carrera, P.A., Stella, M.A. and Chirife, J. 1987. Improvement of thiamine retention in canned low acid foods through $\mathrm{pH}$ adjustment. J. Fd. Sci. 52(3): 827-829.

Correia, L.R. and Mittal, G.S. 1991. pH and colour of meat emulsions during smokehouse cooking. Meat Sci. 29:353364

Frott*, R. and Lewis, A.S. 1994. Canning of meat and fish products. Chapman Hall, London. pp. 202.

Gopal, S.T.K., Mohan, C.O., George, N., and Ravisnkar, C.N. 2012. Potential and future prospects for processing and export of major carps. Fishing Chimes. 32(1): 60-65.

Hamm, R. 1966. Heating of muscle systems. The Physiology and Biochemistry of Muscle as a Food. University of Wisconsin Press, Madison. pp. 363385.

Hochberg, M., Melnick, D. and Oser, B.L. 1945. Colorimetric procedure for thiamine estimation. In: Oser, B.L. (ed.), Hawk's Physiological Chemistry (14th Ed, 1965). McGraw-Hill Book Company, New York, pp. 611-613.

Holdsworth, D. and Simpson, R. 2007. Thermal Processing of Packed Foods. (2nd Ed.). Springer-Verlag New York. pp. 112-114.

Hryniewiecki, L. 2000. Białka. In Zywienieczłowieka. Podstawynaukiozy wieniu. Wydawnictwo Naukowe Warszawa, pp. 176-192. [in Polish].

IS: 2168-1971. 1972. Specification for Pomfret canned in oil: (1st Ed.). Indian Standard Institution, New Delhi, pp. 2328.

Kong, K., Tang, J., Raso, B. and Crapo, C. 2007. Kinetics of salmon quality changes during thermal processing. J. Fd. Engng. 83: 510-520.

Lamden, M.P. 1972. Thiamin. In: Sebrell, W.H.Jr. and Harris, R.S. (ed.), The 
Vitamins, vol.5. Academic press, New York and London. pp. 114-120

Lilabati, H., Bijen, M. and Vishwanath, W. 1993. Comparitive study on nutritive values of fresh and smoked catfish. J. Freshwater. Biol. 5(4): 36-39.

Lokesh, K. R., Chandrasekhar, T. C. and Hanumanthappa, B. 1989. Preservation of tuna shaving by hot smoke curing. Recent Trends in Processing Low Cost Fish (eds. Balachandran, K.K., Perigreen, P.A., Madhavan, P. and Surendran, P.K.). Society of Fisheries Technologist (India), Cochin. Pp. 28-35.

Lovell, R.T. 1979. Off-flavour in pond raised catfish. Highlight of Agric Res. 26(2): 257.

Meilgaard, M., Civille, G.V. and Thomas, B. 2006. Sensory Evaluation Techniques (10th Ed). CRC Press, Florida, pp. 275277.

Miller, E. L., Bimbo, A. P., Walters, D.E., Barlow, S.M. and Sheridan, B. 2000. Ring test for determination of pepsin digestibility in fish meal. INFOMA Research Report, 2000, pp. 18-20.

Mohan, C. O., Ravishankar, C. N., Gopal, T.K.S. and Bindu, J. 2008. Thermal processing of prawn 'kuruma' in retortable pouches and aluminium cans. Int. J. Fd. Sci. Technol. 43: 200-207.

Snedecor, G.W. and Cochren, W.J. 1968. Statistical Methods (6th Ed.). Oxford and IBH Co., New Delhi, pp. 258-266.

Sprent, P. 1989. Kruskal-Wallis and related tests. Applied Non Parametric
Statistical Methods. Chapman and Hall Publication, London, pp. 123-125.

Stumbo, C. R. 1973. Thermo bacteriology in Food Processing (2nd ed.). Academic Press: New York. pp. 93-120.

Swaisgood, H.E. 1985. Characteristics of edible fluids of animal origin. In: Fennema, O.R. (ed.), Food Chemistry, (2nd ed.). Marcel Dekker, New York. pp. 791-827.

Tanaka, M. and Kimura, S. 1988. Effect of heating condition on protein quality of retort pouched fish meat. Nippon Suisan Gakkaisi. 54 (2): 265

Tannenbaum, S. R. 1976. Vitamins and minerals. In: Fennema, O. R. (Ed.), Food chemistry: Principles of food science. Marcel Dekker, New York, 347-381.

Unlusayin, M., Kaleli, S. and Gulyavuz, H. 2001. The determination of flesh productivity and protein components of some species after hot smoking. J. Sci. Fd. Agric. 81(7): 661-664.

Vijayan, P.K., Jose, J., and Balachandran, K.K.1998. Partial drying and smoking to improve the quality of canned catla. Proceedings of advances and priorities in fisheries technology, Kochi, India. Central Institute of Fisheries Technology, India, 242-245.

Zygmunt, U., Joanna, S.R. and Maria, A. 2009. Protein quality and amino acid profiles of fish products available in Poland. Fd Chem. 112: 139-145.

\section{How to cite this article:}

Vishnu R. Nair, P. Dona, Sajan George and Lakshmi R.G. Kumar. 2018. Nutritional and Organoleptic Changes of Grass Carp (Ctenopharyngodon idella, Valenciennes, 1844) Meat upon Smoking and Thermal Processing. Int.J.Curr.Microbiol.App.Sci. 7(08): 4291-4303. doi: https://doi.org/10.20546/ijcmas.2018.708.450 